Military Technical College Kobry El-Kobbah, Cairo, Egypt

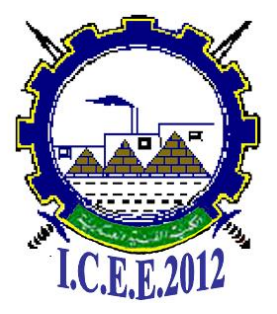

$6^{\text {th }}$ International Conference on

Chemical \& Environmental Engineering 29 -31 May, 2012.

\title{
CPTB-3
}

\section{PHOTOCATALYTIC DECOMPOSITION OF MALATHION USING METAL OXIDE POWDER}

\author{
M.I.Awaad*, M.S.Fayed*, M.K. Abd El Magid*, A. Baraka*
}

\begin{abstract}
Malathion is an organophosphate insecticide used to control a variety of insects in agricultural productions. The contamination of water by malathion and other organophosphate insecticides has a great hazard to the human and animals due to carcinogenic effect and other toxic effects to nerve system. To remove malathion contamination from water, photocatalysis has been applied as a powerful method. Powder form of some selected metal oxide such as $\mathrm{TiO}_{2}, \mathrm{Al}_{2} \mathrm{O}_{3}, \mathrm{Fe}_{2} \mathrm{O}_{3}$, and $\mathrm{MgO}$ was used. Photocatalytic decomposition of malathion at different conditions (malathion initial concentration, catalyst type and catalyst amount in sample and presence of oxidant) were investigated in a patch reactor. $\mathrm{H}_{2} \mathrm{O}_{2}, \mathrm{~K}_{2} \mathrm{~S}_{2} \mathrm{O}_{8}$, $\left(\mathrm{NH}_{4}\right)_{2} \mathrm{~S}_{2} \mathrm{O}_{8}, \mathrm{KMnO}_{4}, \mathrm{CrO}_{3}$ were used as oxidants. Amongst the tested oxides, $\mathrm{TiO}_{2}$ was found to best decompose malathion and decomposition was increased as the concentration of $\mathrm{TiO}_{2}$ was elevated up to $14 \mathrm{mg} / \mathrm{l}$. Addition of $\mathrm{H}_{2} \mathrm{O}_{2}$ to reactor highly enhanced the decomposition process.
\end{abstract}

Key words: Photocatalysis; $\mathrm{TiO}_{2}$; Organophosphorous; Malathion; Decomposition.

\footnotetext{
* Egyptian Armed Forces
} 


\section{Introduction}

Malathion is an organophosphate insecticide used to control a variety of insects in agricultural and nonagricultural purposes. Malathion contaminates the environment via spraying on agricultural crops and at agricultural sites, the malathion contamination can be released back to surface water and soil by wet deposition [1]. The contamination by malathion and other organophosphate insecticides has a great hazard to the human and animals due to carcinogenic effect and other toxic effects to nerve system [2-4]. As a result, many effective treatment methods for eliminating insecticides contamination have been studied. Of these, activatedsludge process was used to treat organophosphorous insecticides wastewaters but with low efficiently due to the resistance of the pesticides to biodegradation [5].

In recent years, $\mathrm{TiO}_{2}$ has been used as an effective photocatalyst for decomposition of a wide range of insecticides, including organophosphorous type [6,7]. Heterogeneous photocatalysis was proved to be a successful method to decompose a large variety of insecticides in water $[8,9]$.

Photocatalytic decomposition using $\mathrm{TiO}_{2}$ as catalyst is especially suitable for decrease or removes the insecticides contamination due to a remarkable activity of $\mathrm{TiO}_{2}$ compared to conventional physical, biological and chemical methods [10,11]. Photocatalysis is the photoexcitation of a solid semiconductor $\left(\mathrm{TiO}_{2}\right)$ via absorption of electromagnetic radiation in the visible and ultraviolet range [12]. Advanced oxidation processes including photodegradation reactions is one of the most promising methods for malathion removal. The photocatalytic decomposition of insecticides defined as a cyclic photo process in which the insecticides decomposed with spontaneous regeneration of catalyst allow the sequence to continue until all the contaminants destroyed $[13,14]$.

In this work, the following parameters were investigated to study the photocatalytic decomposition of malathion: the initial concentration of malathion, the type and amount of applied catalysts, time of exposure, and presence of oxidants (type and amount).

\section{Experimental}

\section{Chemicals}

The following are the chemicals used in this work: Malathion (purity $>95 \%$, Nasr Company for Intermediate chemicals), absolute ethanol $\left(\mathrm{C}_{2} \mathrm{H}_{5} \mathrm{OH}\right.$, Aldrich), Titanium oxide $\left(\mathrm{TiO}_{2}\right.$, commercial, average size $=200 \mu \mathrm{m})$, Aluminium oxide, $\left(\mathrm{Al}_{2} \mathrm{O}_{3}\right.$, Sigma $)$ Ferric oxide $\left(\mathrm{Fe}_{2} \mathrm{O}_{3}\right.$, Sigma), Magnesium oxide (MgO, Sigma), Hydrogen peroxide $\left(\mathrm{H}_{2} \mathrm{O}_{2}\right.$, Aldrich) Potassium peroxydisulfate $\left(\mathrm{K}_{2} \mathrm{~S}_{2} \mathrm{O}_{8}\right.$, Fluka), Ammonium peroxydisulfate $\left(\mathrm{NH}_{4}\right)_{2} \mathrm{~S}_{2} \mathrm{O}_{8}$, Fluka), Potassium permanganate $\left(\mathrm{KMnO}_{4}\right.$, Algomhoria Co.), and Chromium oxide $\left(\mathrm{CrO}_{3}\right.$, Aldrich).

\section{Instrumentation and Operating Conditions}

An Agilent 7890A GC coupled with flame photometric detector was employed for analyzing the contaminated samples before and after decomposition, the operating conditions for analysis of malathion are listed below; 


\begin{tabular}{|l|l|}
\hline GC & Agilent $7890 \mathrm{~A}$ \\
\hline Sampler & Agilent $7683 \mathrm{~B}, 5.0$ - $\mu \mathrm{L}$ syringe \\
\hline Carrier & Nitrogen $2 \mathrm{ml} / \mathrm{min}$. \\
\hline Column & Agilent J\&W HP-5 MS Ultra Inert $30 \mathrm{~m} \times 0.25 \mathrm{~mm} \times 0.25 \mu \mathrm{m}$ \\
\hline Oven & $\begin{array}{l}45^{\circ} \mathrm{C} \text { hold } 1 \mathrm{~min}, \text { to } 110{ }^{\circ} \mathrm{C}\left(20^{\circ} \mathrm{C} / \mathrm{min}\right), \text { hold } 1 \mathrm{~min}{ }^{\circ} \mathrm{C} / \mathrm{min}, \text { to } \\
280{ }^{\circ} \mathrm{C},\left(20{ }^{\circ} \mathrm{C} / \mathrm{min}\right), \text { hold } 1 \mathrm{~min} .\end{array}$ \\
\hline Inlet & $\begin{array}{l}\text { splitless; injector temperature } 250{ }^{\circ} \mathrm{C}, 40 \text { psi until } 0.75 \mathrm{~min}, \\
\text { purge flow } 50 \mathrm{~mL} / \mathrm{min} \text { at } 1.0 \text { min Injection }\end{array}$ \\
\hline Detection & $\begin{array}{l}\text { FPD Phosphorous mode, }, \text { Detector temperature } 250{ }^{\circ} \mathrm{C},\left(\mathrm{H}_{2} 75\right. \\
\mathrm{ml} / \mathrm{min}),(\text { Air } 100 \mathrm{ml} / \mathrm{min}),\left(\mathrm{N}_{2} 60 \mathrm{ml} / \mathrm{min}\right) .\end{array}$ \\
\hline
\end{tabular}

\section{Determining the reference calibration curve of malathion}

Stock solution of malathion was prepared by dissolving $200 \mathrm{mg}$ of malathion in $1000 \mathrm{ml}$ absolute ethanol. A series of standard concentrations were prepared by diluting the stock solution $(20,40,60,80,100 \mathrm{ppm})$. These standards were analyzed by GC/FPD and a calibration curve of malathion concentration Vs. peak height was recorded.

\section{Photocatalytic decomposition experiment}

The photocatalytic decomposition of malathion was conducted in a $250 \mathrm{ml}$ UV reactor showen in figure (1). The reactor houses a UV-source (10W high-pressure mercury lamp, 12 $\mathrm{cm}$, emission wavelength $=254 \mathrm{~nm}$ ).

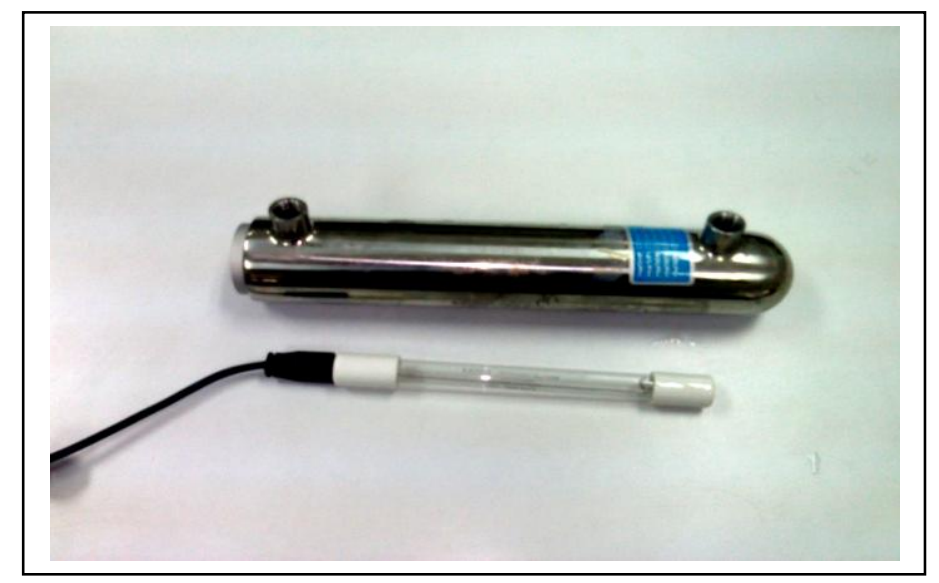

Fig.1. The photochemical cell used in the photocatalytic process

\section{Study the effect of catalyst type}

In order to study the effect of the catalysts on the photo catalysis of malathion, experiments were conducted employing different catalysts $\left(\mathrm{TiO}_{2}, \mathrm{Al}_{2} \mathrm{O}_{3}, \mathrm{Fe}_{2} \mathrm{O}_{3}, \mathrm{MgO}\right)$ using same catalyst concentration $10 \mathrm{mg} / \mathrm{l}$ against same initial concentration of malathion $(200 \mathrm{ppm})$. 


\section{Study the effect of the initial concentration of malathion}

As will be shown shortly, $\mathrm{TiO}_{2}$ gave best results. Accordingly effect of initial concentration of malathion was carried out with $\mathrm{TiO}_{2}$ only. $10 \mathrm{mg}$ of $\mathrm{TiO}_{2}$ powder (Anatas) was added to 100 $\mathrm{ml}$ of malathion solution with different concentrations (100, 200, 300, 400, 500 ppm), malathion solution was Irradiated in the UV reactor. At specific time intervals samples where withdrawn from the reactor and filtered through a $0.7 \mu \mathrm{m}$ filter then centrifuged to remove the $\mathrm{TiO}_{2}$ particles from the solution, and then residual malathion concentrations were determined by GC/FPD.

\section{Study the effect of catalyst concentration}

In order to study the effect of the catalyst's initial concentration on the photocatalysis of malathion, experiments were conducted employing different concentrations of $\mathrm{TiO}_{2}$ varying from 4 to $16 \mathrm{mg} / \mathrm{l}$ while using the same initial concentration of malathion (200 ppm).

\section{Study the effect of oxidant type}

In this study five oxidants was evaluated $\left[\left(\mathrm{H}_{2} \mathrm{O}_{2}(1 \mathrm{mM}), \mathrm{K}_{2} \mathrm{~S}_{2} \mathrm{O}_{8}(1 \mathrm{mM}),\left(\mathrm{NH}_{4}\right)_{2} \mathrm{~S}_{2} \mathrm{O}_{8}(1\right.\right.$ $\left.\mathrm{mM}), \mathrm{KMnO}_{4}(1 \mathrm{mM}), \mathrm{CrO}_{3}(1 \mathrm{mM})\right]$ to enhance the photodecomposition efficiency.

\section{RESULTS AND DISCUSSION}

\section{Study the effect of catalyst type}

The variation in degradation efficiencies of malathion for different catalysts are shown in Figure 2. It is obvious that $\mathrm{TiO}_{2}$ has the higher decomposition efficiency amongest the others. It is clear that after 10 minutes of radiation, the decomposition efficiencies of malathion are $(79,56.5,53.5,31.8)$ for $\left(\mathrm{TiO}_{2}, \mathrm{Al}_{2} \mathrm{O}_{3}, \mathrm{Fe}_{2} \mathrm{O}_{3}, \mathrm{MgO}\right)$ respectively. This difference is related to the characteristics of catalysts, thier surface area, band gap and particle size. Titanium dioxide used have surface area $50 \mathrm{~m}^{2} / \mathrm{g}$, diameter $200 \mu \mathrm{m}$, and band gap $3.2 \mathrm{eV}$, Distigushable of using commercial $\mathrm{TiO}_{2}$-photocatalyst is interesting as cost effective approach.

$\mathrm{TiO}_{2}$ exhibits larger surface area and a smaller particle size which are basicly responsible from one hand, for higher reaction rates at small concentrations, and from the other, for provoking more easily light scattering while on the contrary, the other oxides requires higher amounts in order to achieve similar reaction rates before light scattering takes place $[16,17]$. 


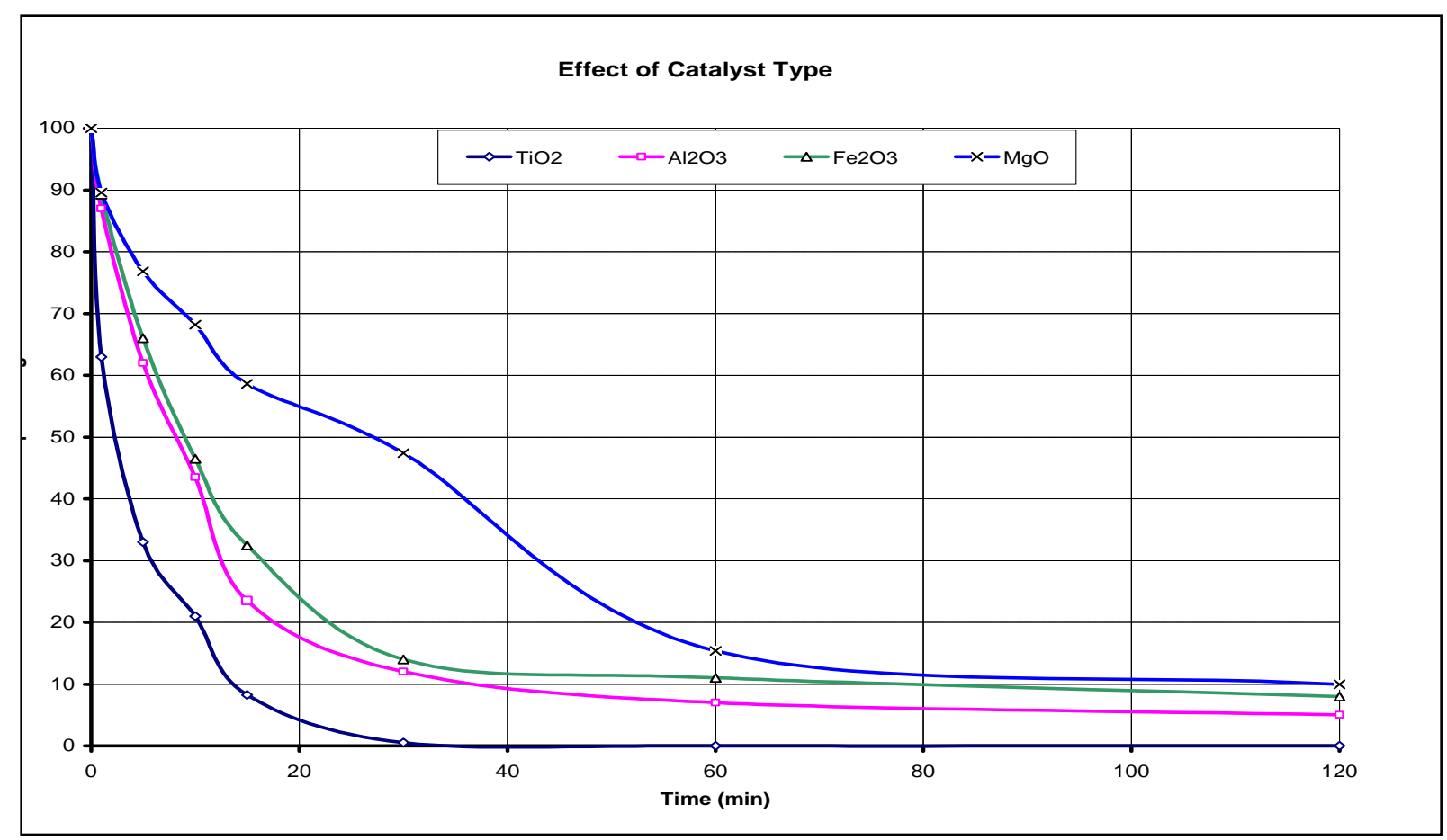

Fig.2. the effect of catalyst type on the photodecomposition process

\section{Study the effect of the initial concentration of Malathion}

The variation in degradation efficiencies of malathion at different initial concentrations of malathion are shown in Figure 3. Obviously, the degradation efficiencies decrease significantly with an increase in the initial concentration of malathion, it was clear that, when the initial concentration of malathion was $100 \mathrm{ppm}$, the degradation efficiency in 20 min was $93 \%$, while at the initial concentration $500 \mathrm{ppm}$, the degradation efficiency was $55 \%$, the same time.

It is reported that the recombination of photogenerated electrons and holes at the surface of $\mathrm{TiO} 2$ can completes within $10^{-9} \mathrm{~s}$, which implies that the contaminants could not be degraded unless they are adsorbed on the surface of $\mathrm{TiO} 2 .[6,15]$, thus surface adsorption process is of paramount importance in controlling the degradation of malathion. At a fixed dosage of TiO2 and consequently constant total sites available for absorption, the degradation efficiency is expected to decrease with an increase in the initial concentration of malathion.

Fig.3, shows that as the initial concentration of malathion increased, the rate of decomposition decreased and the time of decomposition increased 


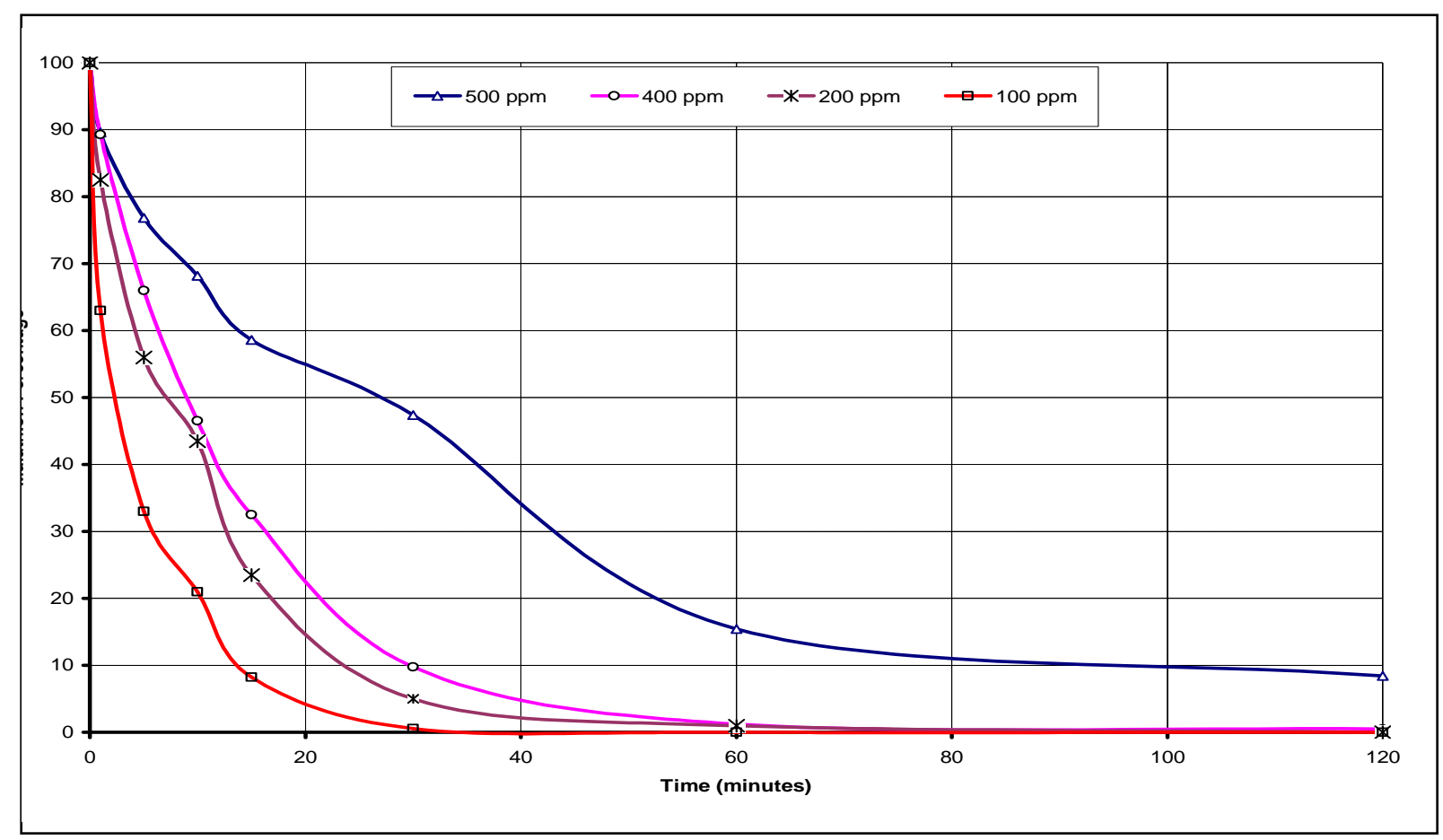

Fig.3. The effect of the initial concentration of malathion on the photodecomposition process

\section{Study the effect of catalyst concentration}

The effect of catalyst concentration on the photocalytic decomposition of malathion was showed in figure 4, It is obvious that the decomposition rate is directly proportional to the concentration of catalystuntill the concentration reached to $100 \mathrm{ppm}$, however, above this value, the decomposition rate becomes independent of the concentration the catalyst, this is due to, the suspended particles of the catalysts block the UV-light passage and increase the light scattering [18].

\section{Effect of the addition of an oxidant}

The addition of an oxidant into a semiconductor suspension has been proven to enhance the photodegradation rate of a variety of organic pollutants.[17,18,19]

the addition of five oxidants $\left[\mathrm{H}_{2} \mathrm{O}_{2}, \mathrm{~K}_{2} \mathrm{~S}_{2} \mathrm{O}_{8},\left(\mathrm{NH}_{4}\right)_{2} \mathrm{~S}_{2} \mathrm{O}_{8}, \mathrm{KMnO}_{4}\right.$, andCrO 3 ] was evaluated at the same conditions and ploted in figure 5, Obviously, the presence of low concentration of oxidant $(1.0 \mathrm{mmol} / \mathrm{L})$ pronouncedly elevated the degradation effeciency of malathion. 


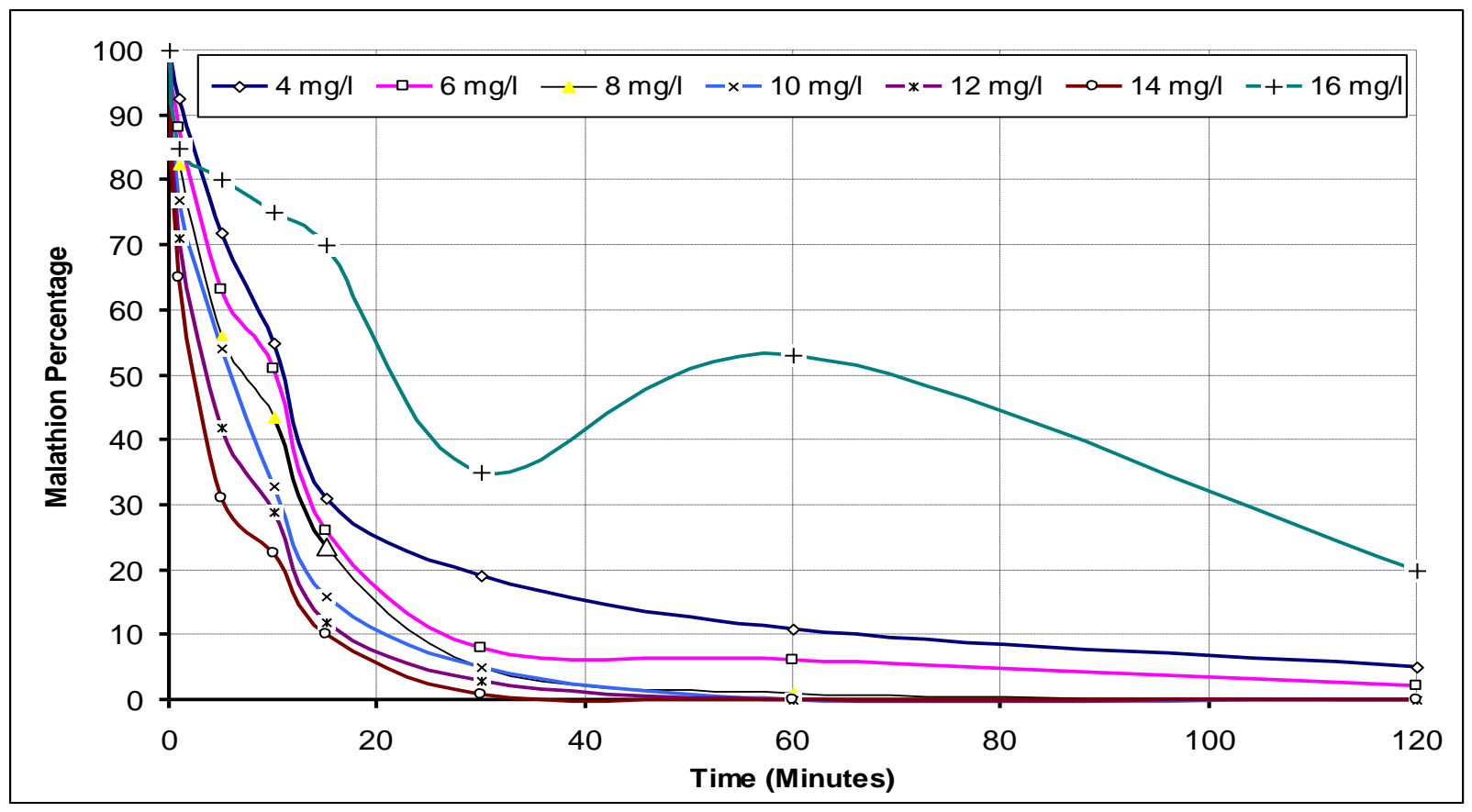

Fig.4. the effect of catalyst concentration on the photodecomposition process

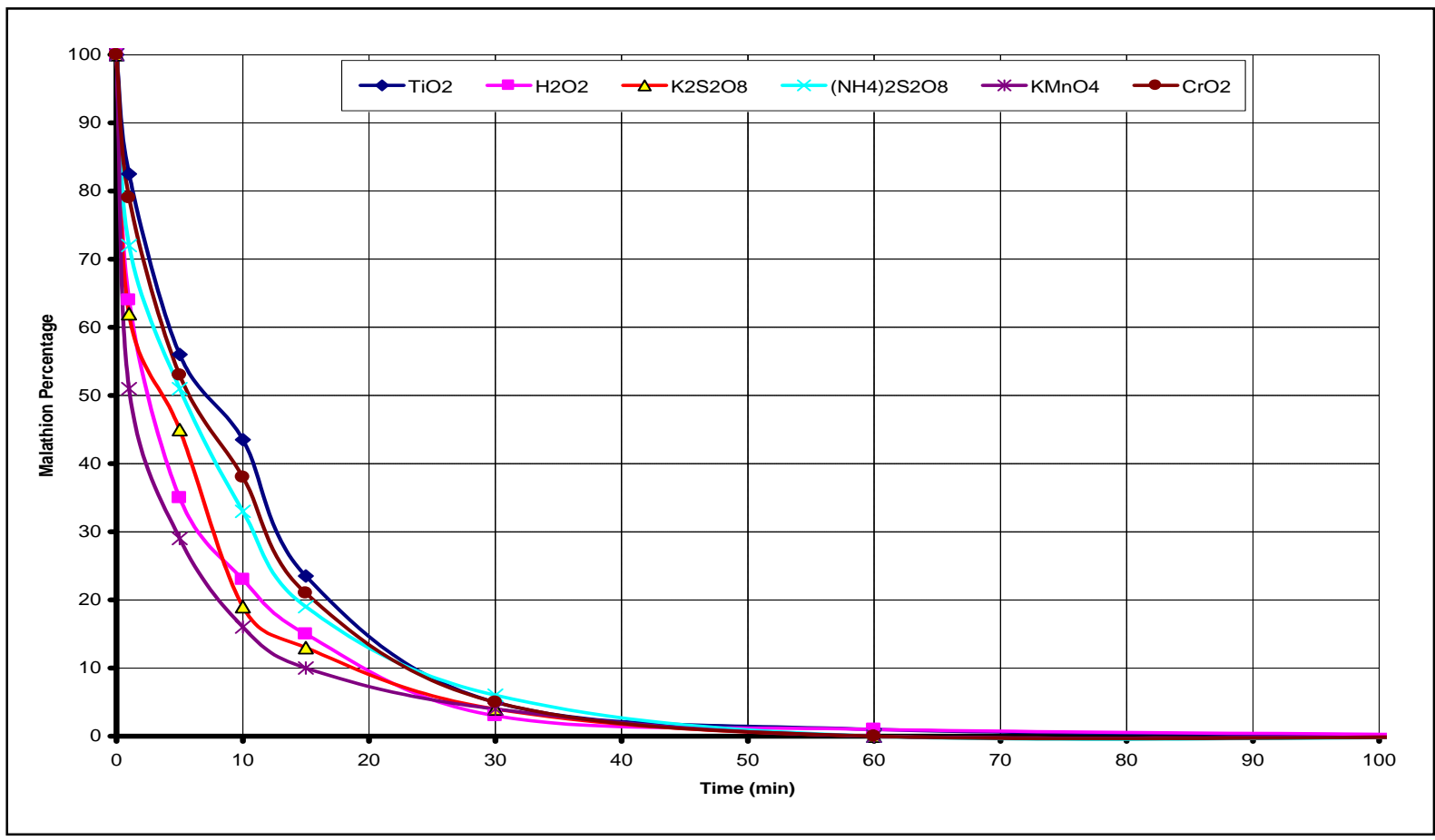

Fig.5. the effect of oxidant type on the photodecomposition process

A further increase in degradation efficiency was not observed with an increase in concentration of oxidant, Instead, a slight decrease occurred when the concentrations of oxidant were above $6.0 \mathrm{mmol} / \mathrm{L}$, 
As strong oxidants,can serve as efficient scavengers of electrons to prevent electron-hole recombination at the surface of catalyst through the following reactions $[17,20]$ :

$$
\begin{aligned}
\mathrm{H}_{2} \mathrm{O}_{2}+\mathrm{e} & \longrightarrow \mathrm{OH}+\mathrm{OH}^{-} \\
\mathrm{S}_{2} \mathrm{O}_{8}^{-2}+\mathrm{e} & \longrightarrow \mathrm{SO}_{4}^{-}+\mathrm{SO}_{4}^{-2}
\end{aligned}
$$

Furthermore, hydroxyl radicals and sulfate radicals, two highly oxidizing species produced in the above reactions, would also contributeto the decomposition of malathion. But, at a concentration high enough, excessive adsorption of $\mathrm{H}_{2} \mathrm{O}_{2} / \mathrm{K}_{2} \mathrm{~S}_{2} \mathrm{O}_{8}$ on $\mathrm{TiO}_{2}$ surface probably prevents malathion from approaching the surface of $\mathrm{TiO} 2$, resulting in a slight decrease in malathion degradation as shown in Fig. 6. In addition, hydroxyl radicals may be scavenged by excessive $\mathrm{H}_{2} \mathrm{O}_{2}$.

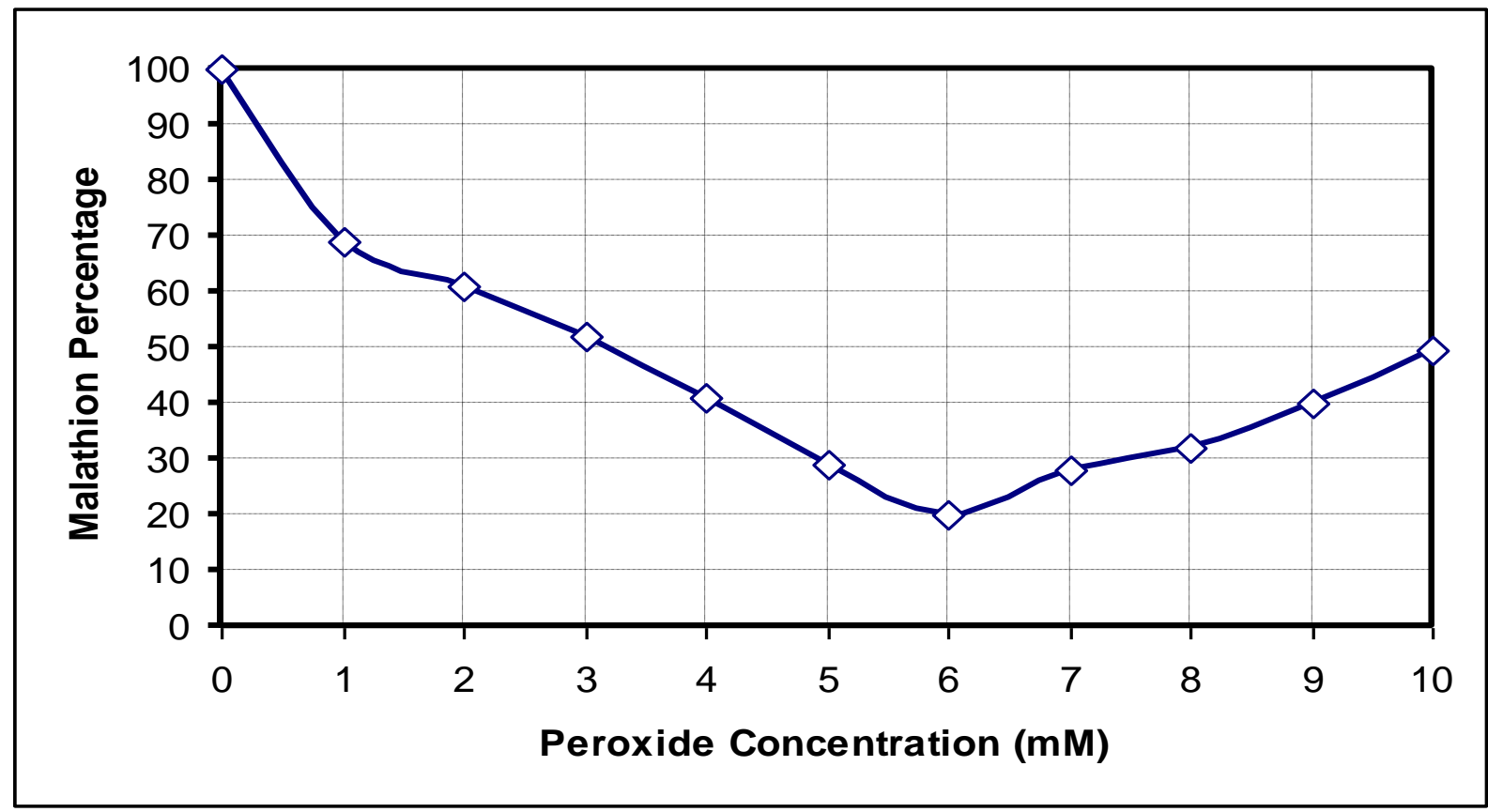

Fig.6. the effect of oxidant concentration on the photodecomposition process

\section{Conclusion}

The photocatalytic decomposition of malathion has been studied using $\mathrm{TiO}_{2}, \mathrm{Al}_{2} \mathrm{O}_{3}, \mathrm{Fe}_{2} \mathrm{O}_{3}$, and $\mathrm{MgO}$ as catalysts., Titanium dioxide proved to be more efficient photocatalyst since the oxidation and decomposition of malathion at higher reaction rates. at optimal operating parameters, the degradation efficiency could reach $100 \%$ in $30 \mathrm{~min}$ when the concentration of malathion is below $100 \mathrm{ppm}$. Titanium dioxide loading has significant effect on the degradation of malathion. The degradation efficiency increases with elevated concentration of $\mathrm{TiO} 2$ suspension up to $14 \mathrm{mg} / \mathrm{L}$, then the efficiency reduced slightly when the concentration is above $14 \mathrm{mg} / \mathrm{L}$ due to a lightshielding effect. The presence of oxidants enhance photodegradation efficiency of malathion. However, the increment in degradation efficiency may be suppressed to some extent due to being scavenged of $\mathrm{OH}$ radicals species by excessive $\mathrm{H}_{2} \mathrm{O}_{2} / \mathrm{K}_{2} \mathrm{~S}_{2} \mathrm{O}_{8}$ at a high concentration level. 


\section{References}

[1] U.S. Department of Health and Human Services, Public Health Service. Agency for Toxic Substances and Disease Registry.2003.

[2] Pham CH, Min J, Gu MB. Pesticide induced toxicity and stress response in bacterial cells. Bull Environ Contam Toxicol 2004;72(2):380-6

[3] B. Kumari, A. Gha, M.G. Pathak, T.C. Bora, M.K. Roy, Experimental biofilm and its application in malathion degradation, Folia Microbiol. 43 (1998) 27-30

[4] T.N. Obee and S. Satyapal, J. Photochem. Photobiol.A: Chem., 118 (1998) 45-51

[5] C. $\mathrm{Xu}$, ed., Pesticide Wastewater Treatment, Chemical Engineering Industry Press, Beijing, 2001 (in Chinese).

[6] Jian-Qiu Chen, Duo Wang, Mao-Xu Zhu, Cong-Jie Gao, Desalination 207 (2007) 8794

[7] R.A. Doong and W.H. Chang, J. Photochem. Photobiol. A: Chem., 107 (1997) 239244

[8] S. Devipriya, S. Yesodharan, Photocatalytic degradation of pesticide contaminants in water, Sol. Energy Mater. Sol. Cells 86 (2005) 309-348

[9] R. Doong, W. Chang, Photoassisted titanium dioxide mediated degradation of organophosphorus pesticides by hydrogen peroxide, J. Photochem. Photobiol. A 107 (1997) 239-244

[10] J.M. Herrmann, C. Guillard and M. Arguello, Catalysis Today, 54 (1999) 353-367

[11] Ekaterina A. Kozlova Journal of Photochemistry and Photobiology A: Chemistry 162 (2004) 503-511

[12] Weichgrebe D. Beitrag zur, Chemish-Oxidativen Abwasserbehandlung. Dissertation, TU Clausthal. (1994)

[13] Mojca B. K, oxidation and degradation of organophosphorous compounds, university of Nova Gorica, 2007

[14] Muszkat L., Bir L., Feigelson L., 1995. Solar photocatalytic mineralization of pesticides in polluted waters. J. photochem. photobiol., A Chem., 87: 85-88).

[15] B. Idriss and V.K. Prashant, J. Phys. Chem., 99 (1995) 9182-9188.

[16] S. Sakthivel, B. Neppolian, M.V. Shankar, B. Arabindoo, M. Palanichamy, V. Murugesan, Sol. Energy Mater. Sol. Cells 77 (2003) 65-82.

[17] E. Evgenidou, K. Fytianos , I. Poulios Journal of Photochemistry and Photobiology A: Chemistry 175 (2005) 29-38

[18] N. Daneshvar, D. Salari, A.R. Khataee, J. Photochem. Photobiol. A: Chem. 6239 (2003) 1-6.

[19] E. Evgenidou, K. Fytianos, I. Poulios, in: T.D. Lekkas (Ed.), Proceedings of the Eighth International Conference on Environmental Science and Technology, Lemnos Island, Greece, 2003.

[20] S. Malato, J. Blanco, M.I. Maldonado, P. Fern’andez-Ib'ãnez, A. Campos, Appl. Catal. B: Environ. 28 (2000) 163-174. 